\title{
THE JEWISH CONTEXT OF PAUL'S GENTILE MISSION
}

\author{
James C. Miller
}

\begin{abstract}
Summary
Luke consistently portrays Paul going first to a synagogue to preach when entering a new location and only later turning to the Gentiles. Many scholars contest this depiction, claiming that the apostle to the Gentiles would not have preached to Jews. Luke's portrayal of Paul on this point, therefore, must be a product of Luke's theology rather than a reflection of Paul's actual practice. On the basis of evidence drawn from the argument of Romans, this essay contends that Paul's apostleship consisted of bringing the Gentile peoples alongside the Jewish people as one people in united praise of God. As such, the nature of Paul's task necessitated working with Jews whenever possible. Such an understanding of Paul's calling not only requires rethinking common understandings of what 'apostle to the Gentiles' meant, it also lends credence to Luke's depiction of Paul's missionary practice.
\end{abstract}

\section{Introduction}

After Paul and Silas had passed through Amphipolis and Apolonia they came to Thessalonica where there was a synagogue of the Jews. And Paul went in, as was his custom, and on three sabbath days argued with them from the scriptures, explaining and proving that it was necessary for the Messiah to suffer and to rise from the dead, saying, 'This is the Messiah, Jesus whom I am proclaiming to you'. (Acts 17:1-3 NRSV)

This description of Paul's activity in Thessalonica corresponds with Luke's consistent depictions of Paul's missionary practice found in the Acts of the Apostles $(13: 5,14 ; 14: 1 ; 16: 13 ; 17: 10,17 ; 18: 4,19 ; 19: 8$; $28: 17,23)$. In each case, Paul, the apostle to the Gentiles, makes it his 
custom when arriving in a new city to go first to the Jews - and only after preaching to them, to turn to the Gentiles.

For many Pauline scholars, this portrayal plays an integral role in their understanding of Paul's missionary methods. ${ }^{1}$ For example, Mark D. Nanos finds in Paul what he labels 'the divine two-step pattern'. This pattern means that Paul's missionary praxis 'begins with the restoration of Israel in each new location first, before the gospel proclamation can fully incorporate gentiles into the people of God'. ${ }^{2}$ Thus, according to Nanos, the pattern depicted by Luke was not merely Paul's method of mission, but one whose origin lay in Paul's understanding of God's salvation-historical design. ${ }^{3}$

Yet, others sharply contest Luke's depiction of Paul's missionary practice, claiming that Paul, as apostle to the Gentiles, would be concerned not with Jews but with Gentiles alone. For these scholars, Luke's portrait of Paul is a product of Luke's theology, not Paul's actual practice. ${ }^{4}$ Although their specific reasons for calling into question Luke's picture of Paul's activity vary, their rejection of that portrait is unequivocal. Thus, Walter Schmithals writes, 'it is almost impossible to imagine Paul beginning his preaching in the synagogues. ${ }^{5}$ E. P. Sanders regards this aspect of Luke's portrayal of Paul as in conflict with the evidence of his letters and therefore to be disregarded lest it distort our picture of Paul. ${ }^{6}$ Sanders concludes that, 'Paul was apostle to the Gentiles. So he styled himself, and so he acted.' 7

1 See, for example, Johannes Munck, Christ and Israel (Philadelphia: Fortress, 1967): 18-19.

2 The Mystery of Romans (Minneapolis: Fortress, 1996): 243 (see also p. 272).

3 See also the work of Jacob Jervell, including, 'The Divided People of God', in Luke and the People of God (Minneapolis: Augsburg, 1972): 41-74; 'The History of Early Christianity and the Acts of the Apostles', in The Unknown Paul (Minneapolis: Augsburg, 1984): 13-25; and The Theology of the Acts of the Apostles (NTT; Cambridge: Cambridge University Press, 1996): esp. 14-15, 82-87.

4 So, for example, Gerd Lüdemann, Early Christianity According to the Traditions in Acts: A Commentary (London: SCM, 1989): 185; Alan F. Segal, Paul the Convert (New Haven: Yale, 1990): 271.

5 Paul and James (SBT 46; London: SCM, 1965): 60. Ernst Haenchen (The Acts of the Apostles. A Commentary [Philadelphia: Westminster, 1971]: 506-7) categorises Luke's portrayal of Paul's activity in the Acts 17 passage above as patently 'false'.

6 Paul, The Law, and the Jewish People (Minneapolis: Fortress, 1983): 181, 190.

7 Sanders, Paul, The Law, and the Jewish People: 190. See also Wayne A. Meeks, The First Urban Christians (New Haven: Yale University Press, 1983): 26; J. Louis Martyn, Theological Issues in the Letters of Paul (Nashville: Abingdon, 1997): 4 n. 3; 
In this paper, I argue for two significant factors regarding Paul's missionary practice and Luke's portrayal of it. First, working from the premise expressed by Nils Dahl, that Paul's 'theology and his missionary activity were inseparable', ${ }^{8}$ I suggest that certain core features of Paul's theology have been overlooked in studies of Paul's missionary strategy and practice. More specifically, I contend that Paul's letters offer important yet neglected evidence for how Paul perceived God's purposes for Jews and Gentiles in his time and how he conceived of his apostolic call. These factors shed light on how he likely carried out his ministry in relation to Jews and Gentiles. Secondly, I suggest these results lend credence to Luke's portrayal of Paul's missionary practice.

In what follows, I restrict myself to the evidence found in Romans. In part this decision stems from limitations of space and a desire to avoid simplistic harmonisation of Paul's letters. Primarily, however, this approach issues from the fact that Romans not only contains Paul's longest surviving sustained argument, but also that this argument concerns the relation of Jews and Gentiles in the eschatological plans of God. For this reason, Romans offers important evidence for the theological resources informing Paul's missionary practice in regard to both groups. ${ }^{9}$

After a lengthy analysis of Paul's reasoning in Romans, I will return to the question of Paul's praxis in light of my findings. This long tour through Romans is necessary, for as I have already asserted, Paul's theology and his missionary conduct were inseparable.

Lloyd Gaston, Paul and the Torah (Vancouver: University of British Columbia Press, 1987): 22.

${ }^{8}$ 'The Missionary Theology in the Epistle to the Romans', in Studies in Paul (Minneapolis: Augsburg, 1977): 70.

9 Leander E. Keck has now undertaken a similar project using Rom. 9-11 rather than, as here, Romans as a whole. See Keck, 'The Jewish Paul Among the Gentiles: Two Portraits', in Early Christianity and Classical Culture: Comparative Studies in Honor of Abraham J. Malherbe, eds John T. Fitzgerald, Thomas H. Olbricht, and L. Michael White (NovTSup, 110; Leiden: Brill, 2003): 461-81. 


\section{Romans}

The activity of writing Romans constitutes a material expression of Paul's apostolic call. ${ }^{10}$ The letter emanates from one self-identified as 'Paul, slave of Jesus Christ, called to be an apostle, set apart for the gospel of God' (1:1). Paul, furthermore, states that he regards the Roman Christians as within his sphere of apostolic activity (1:11-15; possibly 1:6). If writing this letter is a function of Paul's apostolic calling, the purpose of that call and the aim of the letter must somehow coincide.

What, then, is the purpose of Paul's apostleship? Paul provides what may be his clearest statement of his apostolic task in Romans 1:5. He writes that he received his summons as apostle 'in order to bring about the obedience of faith among the Gentiles'. Paul repeats the phrase 'obedience of faith', or something similar, in connection with statements about his call at 15:18 and 16:26. ${ }^{11}$ By his repetition of the phrase in the letter-frame, Paul leaves no doubt for his hearers that comprehending this aspect of his call is important for understanding what he is trying to accomplish through the letter.

Putting two and two together, we may say that Paul writes Romans as part of carrying out his apostolic call, and that, according to Romans, his call consists of bringing about the 'obedience of faith' among the Gentile peoples. We may conclude, therefore, that this letter is written precisely to foster such obedience. In other words, what Paul envisions happening 'on the ground' as a result of this letter being read in Rome is that followers of 'Messiah Jesus' (1:1) there will practise this 'obedience of faith'.

Yet what exactly would such 'obedience' look like if it were embraced by Paul's Roman auditors ${ }^{12}$ The best procedure to follow in

10 On the significance that Paul attaches to his apostleship in Romans, signalled from the opening of the letter, see L. Ann Jervis, The Purpose of Romans (JSNTSup, 55; Sheffield: JSOT Press, 1991): 69-79.

11 The authenticity of Rom. 16:25-27 remains disputed. Although this is a difficult textual decision, I find the evidence for its genuineness more persuasive. See James C. Miller, The Obedience of Faith, the Eschatological People of God, and the Purpose of Romans (SBLDS, 177; Atlanta: Society of Biblical Literature, 2000): 181-86; and I. Howard Marshall, 'Romans 16:25-27 - An Apt Conclusion', in Romans and the People of God, eds Sven K. Soderlund and N. T. Wright (Grand Rapids: Eerdmans, 1999): 170-84. Whether genuine or not, scholars regard it as an accurate summary of the letter. See, for example, the commentaries of Dunn and Fitzmyer.

12 Don B. Garlington has thoroughly analysed the phrase 'obedience of faith' in its historical context in Second-Temple Judaism. Although he draws implications from 
order to grasp what Paul means is to ask what 'obedience' Paul specifically calls for in this letter. ${ }^{13}$

Paul's description of this response progresses from a general exhortation to increasingly specific examples of the same as his argument develops. For the sake of clarity, I will break this progression down into three levels. All three levels are linked by the common theme of worship, the apocalyptic framework of two ages that forms the context for Paul's instructions, and connections between Paul's call and the exhortations themselves. ${ }^{14}$

\subsection{Obedience in Romans: Level One}

At its most general level - what I call 'level one' - the fundamental response Paul seeks to elicit is worship. Paul's first exhortations occur in chapter 6 , where he admonishes his hearers to 'offer' themselves to God. This self-offering serves as the basic expression of their identification with Christ in a post-baptismal new life lived to God. In Romans 12:1, Paul returns to this theme, calling on the Roman Christians to 'offer' themselves collectively to God as one living sacrifice. Such an 'offering' constitutes their 'reasonable service of worship' $(12: 1)$.

Paul places his general call to worship in these passages within the apocalyptic framework of two ages. In the first instance, Paul's contrast between Adam and Christ, and the 'ages' introduced by each, portrayed in 5:12-21, serves as the interpretive context for the argument of the chapter 6. In chapter 12, Paul immediately follows his general admonition of 12:1 with an additional exhortation in 12:2 that explains, still in general terms, what this 'offering' looks like. Paul writes, 'Do not be conformed to the pattern of this age.'

In Romans, such worship stands in stark contrast to the characterisation of sin as a refusal to glorify God or give God thanks (1:21). This

this study for understanding the import of the phrase in Romans, his study fails to ask what this 'obedience' would look like if practised by the Roman Christians. See 'The Obedience of Faith': A Pauline Phrase in Historical Context (WUNT, 2:38; Tübingen: J. C. B. Mohr [Paul Siebeck], 1992) and Faith, Obedience and Perseverance: Aspects of Paul's Letter to the Romans (WUNT, 79; Tübingen: J. C. B. Mohr [Paul Siebeck], 1994).

13 For a more detailed treatment of this theme, see Miller, Obedience of Faith: 49-60.

14 My depiction of these three levels synthesizes the exegesis found in Miller, Obedience of Faith: 75-95. A repeat of the detailed arguments found there goes well beyond the limits of this article. 
refusal to worship is part of a pattern of life characteristic of the age introduced by Adam, an age defined by sin and death (5:12-21). Such is the mode of life to which followers of Christ die in baptism (6:2-14).

In 12:1, Paul also roots his exhortations in his apostolic call. He writes, 'Therefore, I exhort you brothers and sisters, by the mercies of God ...' Along with numerous commentators, I take Paul's mention of 'the mercies of God' to be a reference to Paul's divine call. ${ }^{15}$ Note, for example, how Paul returns to this theme in the immediate context at 12:3. This connection of call and exhortation provides explicit evidence linking Paul's apostolic summons and the specific actions called for by the letter. ${ }^{16}$

In level one, then, Paul calls for his auditors to offer themselves to God. This offering involves making a single, collective presentation of themselves to God (12:1), and walking according to a pattern of life consistent with the character of the eschatological age inaugurated by Christ Jesus.

\subsection{Obedience in Romans: Level Two}

Paul spells out his general instructions in a series of more detailed exhortations in 12:3-15:6, which concern relationships among members of the Christian communities in Rome. ${ }^{17}$ This communal concern is most evident in 12:3-13 and 14:1-15:6. I suggest, however, that this relational focus also characterises 12:14-21 and 13:1-7, passages usually understood to concern dealings with outsiders. ${ }^{18}$ The manner of

15 For more detailed substantiation of this reading of 'mercies of God' in 12:1, see, for example, Victor Paul Furnish, Theology and Ethics in Paul (Nashville: Abingdon, 1968): 102; James D. G. Dunn, Romans 9-16 (WBC, 38B; Milton Keynes: Word, 1991): 709; Hans Wilhelm Schmidt, Der Brief des Paulus an die Römer (THKNT, 6; Berlin: Evangelische Verlagsanstalt, 1962): 207. Samuel Bénétreau emphasises the sense of divine authority Paul brings to bear on his exhortation in 12:1 by his use of the imperative парак $\alpha \lambda \tilde{\omega}$ ('I exhort'). Yet Bénétreau misses the way Paul bolsters that authority in the very next phrase by Paul's assertion of his divine call (L'Epitre de Paul aux Romains [CEB 19; Vaux-sur-Seine: Édifac, 1997]: 2.131-32).

16 Once again, I call attention to how L. Ann Jervis establishes the importance of Paul's apostleship for Romans as a whole (Purpose of Romans: 69-79).

17 Kuo-Wei Peng argues that the exhortations of $12: 9 \mathrm{bc}$ serve as the general statements spelled out by way of examples through 15:13. This overlooks the function of 12:1-2 within this section. See my review of Peng's Hate the Evil, Hold Fast to the Good: Structuring Romans 12.1-15.1 [sic] (JSNTSup, 300; London: T \& T Clark, 2006), in $C B Q 69$ (2007): 160-62.

18 Kent L. Yinger has argued persuasively that Rom. 12:14-21, a section typically considered as instructions regarding relations with those outside the Christian communities, refers to relations among community members. Although this runs 
relating to one another depicted in these chapters constitutes the 'offering' Paul's auditors are to make of themselves to God. This is their 'reasonable act of worship' (12:1), carried out as a result of having a mind 'renewed' (12:2. contra 1:28), rather than one conformed to the pattern of 'this present age' (12:2). Thus, the 'pattern' spoken of in 12:2 concerns two fundamentally different manners of relating to one another. The first flows from a mindset shaped by the power of sin and death. The second follows the pattern described beginning in 12:3 and is a product of a mind set 'on what the Spirit desires' (8:5).

This relationship between general admonitions in 12:1-2 and specific examples of those same instructions in 12:3-15:6 highlights the importance of the connection between Paul's call and these instructions. If, as Paul states, the exhortations of 12:1-2 arise from his apostolic call, then the specific examples of those same instructions retain that identical point of origin. Paul's unambiguous restatement of this connection between call and exhortation in 12:3, at the beginning of his more detailed directions, further confirms this link.

\subsection{Obedience in Romans: Level Three}

At level three, the exhortations begun in chapter 6, picked up again at the beginning of chapter 12, and spelled out in greater detail in 12:315:6, culminate at 15:7 with the climactic command for the divided Roman Christians to 'receive one another as Christ received you to the glory of God'. This is the specific 'obedience' Paul has been driving towards all along. ${ }^{19}$ When Paul's Roman auditors truly offer them-

against the grain of traditional scholarly opinion, I am convinced Yinger has now placed the burden of proof on this matter firmly with those who hold the traditional position. See 'Romans 12:14-21 and Nonretaliation in Second Temple Judaism: Addressing Persecution within the Community' $C B Q 60$ (1998): 74-96. Rom. 13:1-7, the other pericope in this section of Romans typically construed as instructions regarding outsiders is one of the most difficult passages in all Paul's writings. In all likelihood, a definitive understanding of what Paul is up to in this passage will never be realised owing to the paucity of our historical knowledge. In my opinion, the article by Johannes Friedrich, Wolfgang Pöhlmann, and Peter Stuhlmacher offers the best explanation of this passage in its historical and literary context. They contend that Paul addresses divisions among Romans believers over Nero's tax policies, thus making these instructions a matter of relations among Roman Christians. See 'Zur historischen Situation und Intention von Röm 13,1-7', ZTK 73 (1976): 131-76. For my own detailed analysis of these passages, see Obedience of Faith: 163-73.

19 See Miller, Obedience of Faith: 61-95, for a thorough treatment of the role of 15:7 within the argument of the letter. 
selves to God, they will accept one another in this way and God will be glorified.

As at levels one and two, the themes of worship, Paul's 'two-age' historical framework and his apostleship play a vital role. Worship takes centre stage, since God is glorified (15:7) when the 'strong' and 'weak' Roman Christians engage in mutual acceptance. Furthermore, Paul contends that his auditors should accept one another because of the work of Christ, cited in 15:8-9a. It is precisely this work, so Paul has argued throughout the letter, that has sounded the death knell for 'this present age' and signalled the dawning the 'age to come'. And, finally, it is this work that constitutes the key component of the 'gospel' he has been called to announce (1:1-5).

\subsection{Conclusion: Obedience in Romans}

I conclude, then, that the 'obedience' Paul works to foster among the Roman Christians consists generally of worship; namely, of offering themselves to God. More specifically, that offering takes concrete form in the manner in which the Roman Christians relate to one another. Finally, and most specifically, this worship becomes reality when the Roman Christians, divided over what to observe or not observe of Jewish traditions (14:1-15:6), welcome one another in a manner reflecting Christ's own welcoming of them.

The exhortation of Romans 15:7 thus becomes the goal towards which Paul's argument has been moving throughout the course of the letter. ${ }^{20}$ If, after hearing this letter read in their meetings, the Roman Christians 'obey' and accept one another, Paul will have succeeded in this one instance in fulfilling his call.

\section{Fulfilling Paul's Call}

Yet, why does this mutual reception fulfill Paul's calling? In order to answer that question, we must first note whom it is that 'obeys' in this fashion in Romans.

20 I substantiate this claim in some detail in Miller, Obedience of Faith: 61-95. See also N. T. Wright, 'Romans and the Theology of Paul', in Pauline Theology, Volume III: Romans, eds David M. Hay and E. Elizabeth Johnson (Minneapolis: Fortress Press, 1995): 36. With reference to Romans 15:7-13, Richard B. Hays ('Adam, Israel, Christ', in Hay and Johnson, Pauline Theology, 81) writes, 'The unification of Jews and Gentiles in the praise of God is the goal toward which the whole letter drives.' 
Along with numerous others, ${ }^{21}$ I contend that Paul understands his audience to consist of a mix of believers from Jewish and Gentile backgrounds and that he directs his call for mutual reception in 15:7 to two groups that fall generally along these lines. ${ }^{22}$ I will briefly summarise the rationale for this conclusion as follows.

Most scholars now agree that Paul's argument in chapters 1-11 primarily concerns not how an individual finds God, but the relationship between Jews and Gentiles in the plan of God. Most would also agree that the exhortations of chapters 12-15 flow from the argument of chapters 1-11. In other words, the exhortations find their basis in Paul's argument about the relation of Jews and Gentiles now that the 'new age' is dawning. The exhortations must, therefore, maintain some relationship to this argument. Once again, most agree that Paul's instructions to the 'strong' and the 'weak' beginning at 14:1 address a genuine issue among the Roman Christians. The matter in dispute concerns what to observe or not observe of Jewish customs rooted in Mosaic Law. Finally, in 15:8-9a, Paul reinforces his exhortation of 15:7 for mutual acceptance by an appeal to the work of Christ on behalf of Jews and Gentiles. This work and its implications were the topic of discussion in chapters 1-11 and Paul's terse summary of Christ's work echoes that argument at several points. An appeal to the work of Christ distinctly for two groups, Jews and Gentiles, is a strange way to drive his exhortation home unless the divisions in Rome fell somewhat along Jew/Gentile lines. ${ }^{23}$

In light of the evidence produced so far, we can return to our original question. Why would mutual acceptance between these groups constitute the 'obedience' Paul was called to foster? The answer to that question lies in Paul's support in 15:8-12 for his exhortation of verse 7.

21 This continues to be the majority position among scholars, though recent years have witnessed a trend toward understanding Paul's hearers as Gentile only.

22 I make no claim regarding the percentages of Paul's auditors from each of these groups. In all likelihood the Gentiles were in the majority. I merely maintain that the letter provides evidence of auditors from both Jewish and Gentile backgrounds.

23 One commonly hears that Paul only addresses Gentiles in Romans, whomever he thought might actually hear the letter. That Paul calls for mutual reception between these two groups at this climactic point in his argument tells decisively against such a claim. For the former argument see, for example, Stanley K. Stowers, A Rereading of Romans (New Haven: Yale University Press, 1994): 21-22, 30) and Paul J. Achtemeier, 'Unsearchable Judgments and Inscrutable Ways', in Pauline Theology, Volume IV: Looking Back, Pressing On, eds E. Elizabeth Johnson and David M. Hay (Atlanta: SBL, 1997): 8. 
As I argued above, in 15:8-9a, Paul succinctly summarises his argument of chapters 1-11 concerning the work of Christ for Jews and Gentiles in order to drive home his call for mutual acceptance. ${ }^{24}$ Paul writes that Christ served the Jewish people in order to confirm the truthfulness of God (15:8). In other words, Christ demonstrated God's covenant faithfulness, a central theme in the letter. Yet, Christ also became a servant to the Gentiles (15:9a), extending God's mercy to them, an argument echoing key points of chapters 3-4, 9-11.25

The litany of quotations that follow in verses $9 \mathrm{~b}-12$ make it plain that Christ confirmed the promises to the ancestors precisely by inaugurating the long-anticipated time when the Gentiles would join the people of God. Citing passages from the Law (Deut. 32:43), Prophets (Isa. 11:10) and Writings (Ps. 17:50; 117:1), Paul recalls the past promises of a future day when the nations would join the Jewish people in united praise of God.

Here then is the force of Paul's argument. The followers of Christ in Rome, divided along Jew/Gentile lines, must embrace their calling as the eschatological people of God. ${ }^{26}$ God's purpose for this time is to form one people drawn from all nations. If the believers in Rome persist in following patterns of relating to one another drawn from the age of Adam, they will persist in sin. If, on the other hand, they rightly understand God's purpose for the time in which they live, with renewed minds they will see their situation in a fresh light, take up their calling, and act accordingly.

This explains Paul's comment in 15:7 that when his auditors accept one another, God will be glorified. God will be glorified precisely because God's will (recall 12:2) for God's eschatological people will be realised in Rome. As Leander Keck observes, the unity for which Paul calls in 15:7

\footnotetext{
24 Richard B. Hays ('Adam, Israel, Christ': 84) finds the 'fundamental message of Romans ... encapsulated in 15:8-9a'.

25 For this interpretation of Jesus' role as depicted in 15:8-9a, see J. Ross Wagner, 'The Christ, Servant of Jew and Gentile: A Fresh Approach to Romans 15;8-9', JBL 116 (1997): 473-85. Regarding the relationship of the preaching to the Gentiles with the promises to Israel as portrayed in Paul's preaching in Acts, see Jacob Jervell, 'Paul in the Acts of the Apostles. Tradition, History, Theology', in The Unknown Paul: 71.

26 Philip F. Esler (Conflict and Identity in Romans [Minneapolis: Fortress, 2003]) describes how Paul labours to foster a new 'social identity' among his auditors in Rome. This is another way, albeit one much more thoroughly substantiated, of stating what I call 'embracing their calling' as the eschatological people of God.
} 
... is not simply a mutual, intramural accommodation to be reached in Rome, but a local instance of God's saving purpose in Christ - the eschatological unity of all people, concretely Jew and Gentile. By coming back to this theme, Paul draws a thread through the entire letter and shows that in Scripture God has indeed promised in advance the gospel for all humanity $(1: 2){ }^{27}$

Thus, this manner of relating to one another is consonant with their identity in Christ among God's eschatological people.

\section{Implications for Understanding Paul's Missionary Practice}

With this reading of Romans in mind and considering the link between Paul's theology and practice, it follows that, if at all possible, Paul simply could not conduct his mission apart from contact with Jews. ${ }^{28}$ As the 'apostle to the Gentiles', Paul's task is not to scoot around the northeastern Mediterranean basin forming independent, pristinely Gentile communities of God's people. Rather, if Paul is to be anywhere near faithful to his call within the purpose of God for Paul's historic moment, he must work to 'graft' the 'wild olive shoots' of God's people called from among the nations on to the roots of the Jewish olive tree (Rom. 11:17). ${ }^{29}$ Together this one people drawn from all nations will constitute the eschatological people of God. Luke's portrait of Paul's strategy of preaching first in a synagogue, therefore, seems hardly out of place.

\footnotetext{
27 'Christology, Soteriology, and the Praise of God (Romans 15:7-13)' in Robert T. Fortna and Beverly R. Gaventa, eds, The Conversation Continues: Studies in Paul \& John In Honor of J. Louis Martyn_(Nashville: Abingdon, 1990): 93-94.

28 Dieter Zeller ('Theologie der Mission bei Paulus', in Karl Kertelge, ed., Mission im Neuen Testament, [Quaestiones Disputatae, 93; Freiburg: Herder, 1982]: 184) writes of Paul, 'Er kennt keine selbständige Weltmission, die nicht mit der Bestimmung seines Volkes verknüpft ware' ('he recognises no independent world mission that would not associate with the destiny of his people'). Contra Jürgen Becker (Paul: Apostle to the Gentiles [Louisville: Westminster John Knox, 1993]: 92) who asserts that Paul's mission was to found Gentile churches 'independent from the synagogue'.

29 Bengt Holmberg states, Paul 'never intended to found a new "Gentile Christianity", he extended the one and only "Israel of God" (Paul and Power [Philadelphia: Fortress, 1980]: 69). See also Lucien Legrand, Unity and Plurality. Mission in the Bible (New York: Orbis, 1990): 126. Contra, for example, J. Louis Martyn's depiction of two missions, one to Jews and one to Gentiles running along 'two lines completely parallel to one another' (Galatians [AB, 33A; New York: Doubleday, 1997]: 180). On the importance of the olive tree metaphor for understanding Paul's comprehension of his mission, see Keck, 'Jewish Paul'.
} 


\section{A Further Question}

Yet, how do we relate the argument laid out above with evidence of distinct missions to Jews (Peter) and to Gentiles (Paul) found in Galatians 2:9 ${ }^{30}$ Paul reports that his visit to Jerusalem with Barnabas produced an agreement with the 'pillars' of the church there that 'we should go to the Gentiles and they to the circumcision' (NRSV). ${ }^{31}$ If Paul was partner to such an agreement, why would he preach in the synagogues as Luke indicates?

I suggest that the evidence of differing missions from Galatians must be fitted within what we know of Paul's call as reconstructed above; not the other way around. ${ }^{32}$ The danger lies in reading the Galatians passage, as so often seems to be done, as evidence for two so-called 'denominations' within early Christianity. Surely there was not a Jewish church on this corner in Corinth and a Gentile one on the next. In response to the division of labour laid out in Galatians 2:9, Christopher Rowland writes,

What is not clear is how it would have been possible to maintain a precise demarcation between these different spheres ... it is difficult to see how there could have been anything but overlap between Christian missionaries in their activities. The apostle to the circumcision is unlikely to have confined himself only to Christians of Jewish extraction, as in the synagogues he would have preached to Gentile sympathizers. What is more, the synagogue must have been a legitimate

30 The exact nature of the two missions spelled out in this agreement constitutes a notoriously difficult exegetical crux. The two primary interpretive options read the division (1) geographically, with Paul going to the Gentile lands and Peter working within the land of Israel or (2) ethnically, with Paul conducting a Law-free mission strictly to non-Jews while Peter engaged in a Law-observant mission among Jews only. Scholars posit numerous variations within these two basic approaches.

31 Regarding the agreement depicted in Gal. 2:9, Walter Schmithals (Paul and James: 45) writes, 'The working of this arrangement is unequivocal. Paul concerns himself with the Gentile mission free from the control of the Law, the mission to the Jews is the task of the Jewish Christians of Jerusalem.'

32 J. Louis Martyn notes that only two passages in Paul's generally accepted letters, 1 Cor. 9:19-23 and 2 Cor. 11:22-28, offer support for Luke's depiction of Paul's missionary methods. According to Martyn (Galatians: 213-14), such sparse evidence argues against Luke's portrayal since Paul's letters, not Acts, must be given primacy for reconstructing Paul's missionary practice. My contention, on the contrary, is that Paul's argument through Romans as a whole supports Luke's description of Paul's missionary methods. Much more textual evidence from Paul, therefore, corroborates what we find in Acts than Martyn allows. On the passages from 1 and 2 Cor., see Leander E. Keck, 'Jewish Paul': 472-73. 
sphere of Paul's activity, in so far as there were many Gentiles connected with it who would not hear the gospel otherwise. ${ }^{33}$

Rowland is not alone in pointing out the difficulties presented by positing strictly separate missions. ${ }^{34}$

In addition, evidence from Paul outside of Galatians argues against a strict division of labour. For example, in Romans, where Paul so strongly asserts his call to the Gentiles, he just as emphatically affirms the salvation-historical priority of the Jewish people $(2: 9-10 ; 3: 1-2$; 9:4-5; 11:1-2, 24, 28-29). Romans 9-11 testifies to Paul's concern for both Gentiles and Jews and 2 Corinthians 11:24 offers positive evidence of Paul's continued contact with the synagogue.

On the basis of the evidence in Paul's letters and in Acts, and upon the reading of Romans outlined above, I conclude that the division of labour spelled out in Galatians 2:9 stipulated broad, overlapping areas of responsibility rather than an airtight division between two distinct missions. ${ }^{35}$ Furthermore, the confusion that seems to follow this

33 Christian Origins (London: SPCK, 1985): 217. For similar reservations about simplistic divisions between Jewish and Gentile missions, in addition to the sources cited in note 17, see esp. F. F. Bruce, The Epistle to the Galatians, (NIGTC; Grand Rapids: Eerdmans, 1982): 125. Bruce writes,

it must have been difficult to define the boundaries of the two mission-fields. There were Jewish colonies in most of the great cities of the eastern Mediterranean world: were the Jerusalem leaders debarred from evangelizing the Jews of Ephesus, Corinth or Rome? Almost certainly not. But since the churches founded in those cities comprised both Jewish and Gentile converts, some overlapping of the two spheres was inevitable. Again, was Paul debarred from visiting synagogues in Gentile cities, if only to evangelize the Gentile God-fearers who attended the services? ... the diversity of Christendom has to be recognized as well as its unity, and whatever may be concluded today about the logic of the firstcentury situation, those who were involved in the situation saw it differently. Godfearing Gentiles, who provided the nucleus of the church in many cities, were more conveniently found in synagogues, but Paul could not preach to them there without preaching to Jews at the same time.

34 See, for example, Martin Hengel, Acts and the History of Earliest Christianity (Philadelphia: Fortress, 1979): 120; C. K. Barrett, Paul: An Introduction to His Thought (Louisville: Westminster/John Knox, 1994): 29; Dieter Georgi, Remembering the Poor: The History of Paul's Collection for Jerusalem (Nashville: Abingdon, 1992): 32; Jerome Murphy-O'Connor, Paul: A Critical Life (New York: Oxford University Press, 1997): 142-43. Jacob Jervell argues that Acts presents Paul as a missionary primarily to the Jews (see the references in footnote 3 above). This is not the place to recount and respond to Jervell's argument in detail. I merely note that, although it is overstated (he neglects evidence of Paul's missions to the Gentiles), he does present a detailed, exegetically-supported argument for a far more Jewish-oriented Pauline ministry in Acts than is customary.

35 Ferdinand Hahn (Mission in the New Testament [SBT, 47; London: SCM, 1965]: 81) states that the agreement of Gal. 2:9, 'does not denote a division into two 
agreement, not only in Antioch, but in other places as well, suggests that soon after this aspect of the agreement was reached, confusion over its interpretation caused whatever concord had been achieved on this matter to lapse (though it may have continued a long time in some places). ${ }^{36}$

\section{Summary}

Paul's lengthy letter to the Romans depicts an apostle summoned to bring the Gentile peoples alongside the Jewish people in united praise of God. ${ }^{37}$ I contend that this fundamental understanding of Paul's call, so evident in Romans, has been overlooked in studies of Paul's missionary practice. Since Paul's theology and his practice were inseparable, Paul could not have attempted to carry out his call by means of a Gentile mission in isolation from the Jewish people. ${ }^{38}$ In light of the findings laid out above, a strictly 'Gentile-only' understanding of Paul's apostolic field of vision becomes inconceivable. This conclusion calls into question influential understandings of Paul as 'apostle to the Gentiles' such as those cited at the outset of this article. Our understanding of that phrase requires reformulation in

missionary spheres, nor does it mean that the one side has to devote itself only to Gentiles and the other to Jews; it rather indicates the main emphasis and purpose of the missionary activity'. Roy E. Ciampa (The Presence and Function of Scripture in Galatians 1 and 2 [WUNT, 2:102; Tübingen: Mohr-Siebeck, 1998]: 146, 237) speaks of the two missions having a complementary but not mutually exclusive 'focus'. Cf. Georgi, Remembering the Poor: 32; Richard N. Longenecker, Galatians (WBC, 41; Dallas: Word, 1990): 59; Günther Bornkamm, Paul (New York: Harper \& Row, 1971): 39-40; W. S. Campbell, 'Paul's Missionary Practice and Policy in Romans', IBS 12 (1990): 15-16; Ronald Y. K. Fung, The Epistle to the Galatians (NICNT; Grand Rapids: Eerdmans, 1998): 100.

36 Holmberg, Paul and Power: 31; Alan F. Segal, Paul the Convert: 190-91; Martyn, Galatians: 206, 220-22; H. J. Schoeps, Paul: The Theology of the Apostle in the Light of Jewish Religious History (Philadelphia: Westminster, 1961): 68. I owe the parenthetical remark to a suggestion made by I. Howard Marshall. For one plausible suggestion as to how this agreement may have broken down, see Becker, Paul: 92-93.

37 As noted above, Paul speaks of God grafting the wild olive shoots of Gentiles on to existing root of Jews (11:17). Such 'grafting' may serve as an apt metaphor for Paul's apostolic activity.

38 Rainer Riesner (Paul's Early Period [Grand Rapids: Eerdmans, 1998]: 246) claims that Paul's statement in Rom. 15:8 that Christ became a servant of the circumcision in order to confirm the promises to the patriarchs "demonstrates that without an origin rooted in the ancient Jewish people of God, neither is there any hope for the Gentiles (15:8-13)'. 
terms that take into account the relationship of Jews and Gentiles in the eschatological people of God. ${ }^{39}$

Furthermore, on the basis of Paul's theology expressed in Romans, Luke's rendering of Paul's missionary practice, dare I say it, 'to the Jew first and also to the Greek', becomes readily understandable. ${ }^{40} \mathrm{I}$ am not claiming that Paul had to go to the Jews first in any given location nor that his mode of operation could not have changed somewhat over time. I do contend that Paul's customary practice as depicted in Acts becomes fully understandable in light of the nature of his calling portrayed in Romans. Thus, for Luke to say that upon arriving at Iconium, Paul and Silas went into the synagogue katò tò aútò ('as was their custom'; 14:1) ${ }^{41}$ should bring no surprise. Paul was sent to the Gentiles to announce God's fulfilment of divine promises made to the Jews, promises that could not be fulfilled apart from the Jewish people. ${ }^{42}$

39 For a similar understanding of Paul's call based on evidence from Romans, see J. Ross Wagner, Heralds of the Good News (NovTSupp, 101; Leiden: Brill, 2002).

40 For the connection between this phrase and Paul's missionary praxis, see also Nanos, Mystery: 239 n. 1; and C. K. Barrett, The Acts of the Apostles (ICC; Edinburgh: T \& T Clark, 1994): 1.611.

41 In support of this translation, see Barrett, The Acts of the Apostles: 1.667. See also F. F. Bruce, The Acts of the Apostles (Grand Rapids: Eerdmans, 1979): 277.

42 I wish express my gratitude to I. Howard Marshall and W. Paul Bowers who read and commented on earlier drafts of this article. 